\title{
Article \\ Trueperella pyogenes Isolates from Livestock and European Bison (Bison bonasus) as a Reservoir of Tetracycline Resistance Determinants
}

\author{
Ewelina Kwiecień ${ }^{1, *}$, Ilona Stefańska ${ }^{1}$, Dorota Chrobak-Chmiel ${ }^{1}$, Magdalena Kizerwetter-Świda ${ }^{1}$, Agata Moroz ${ }^{2}$, \\ Wanda Olech ${ }^{3}{ }^{(D}$, Marina Spinu ${ }^{4}\left(\mathbb{D}\right.$, Marian Binek ${ }^{1}$ and Magdalena Rzewuska ${ }^{1, *(\mathbb{D})}$
}

1 Department of Preclinical Sciences, Institute of Veterinary Medicine, Warsaw University of Life Sciences, Ciszewskiego 8 St., 02-786 Warsaw, Poland; ilona_stefanska@sggw.edu.pl (I.S.); dorota_chrobak@sggw.edu.pl (D.C.-C.); magdalena_kizerwetter_swida@sggw.edu.pl (M.K.-Ś.); marian_binek@sggw.edu.pl (M.B.)

2 Division of Veterinary Epidemiology and Economics, Institute of Veterinary Medicine, Warsaw University of Life Sciences, Nowoursynowska 159c St., 02-786 Warsaw, Poland; agata_moroz@sggw.edu.pl

3 Department of Animal Genetics and Conservation, Institute of Animal Sciences, Warsaw University of Life Sciences, Ciszewskiego 8 St., 02-786 Warsaw, Poland; wanda_olech@sggw.edu.pl

4 Department of Infectious Diseases and Preventive Medicine, Law and Ethics, University of Agricultural Sciences and Veterinary Medicine, Calea Mănăștur 3-5, 400372 Cluj-Napoca, Romania; marina.spinu@usamvcluj.ro

* Correspondence: ewelina_kwiecien@sggw.edu.pl (E.K.); magdalena_rzewuska@sggw.edu.pl (M.R.); Tel.: +48-225-936034 (E.K.); +48-225-936032 (M.R.)

updates

Citation: Kwiecień, E.; Stefańska, I.; Chrobak-Chmiel, D.

Kizerwetter-Świda, M.; Moroz, A.; Olech, W.; Spinu, M.; Binek, M.;

Rzewuska, M. Trueperella pyogenes Isolates from Livestock and European Bison (Bison bonasus) as a Reservoir of Tetracycline Resistance Determinants. Antibiotics 2021, 10, 380. https:// doi.org/10.3390/antibiotics10040380

Academic Editor: Elena Perrin

Received: 15 February 2021

Accepted: 31 March 2021

Published: 3 April 2021

Publisher's Note: MDPI stays neutral with regard to jurisdictional claims in published maps and institutional affiliations.

Copyright: (c) 2021 by the authors. Licensee MDPI, Basel, Switzerland. This article is an open access article distributed under the terms and conditions of the Creative Commons Attribution (CC BY) license (https:/ / creativecommons.org/licenses/by/ $4.0 /)$.
Abstract: Determinants of tetracycline resistance in Trueperella pyogenes are still poorly known. In this study, resistance to tetracycline was investigated in 114 T. pyogenes isolates from livestock and European bison. Tetracycline minimum inhibitory concentration (MIC) was evaluated by a microdilution method, and tetracycline resistance genes were detected by PCR. To determine variants of tet $W$ and their linkage with mobile elements, sequencing analysis was performed. Among the studied isolates, $43.0 \%$ were tetracycline resistant (MIC $\geq 8 \mu \mathrm{g} / \mathrm{mL}$ ). The highest $\mathrm{MIC}_{90}$ of tetracycline $(32 \mu \mathrm{g} / \mathrm{mL})$ was noted in bovine and European bison isolates. The most prevalent determinant of tetracycline resistance was tet $W$ (in $40.4 \%$ of isolates), while tet $A(33)$ was detected only in $8.8 \%$ of isolates. Four variants of tet $W$ (tet $W-1$, tet $W-2$, tet $W-3$, tet $W-4$ ) were recognized. The tet $W-3$ variant was the most frequent and was linked to the ATE- 1 transposon. The tet $W-2$ variant, found in a swine isolate, was not previously reported in T. pyogenes. This is the first report on determinants of tetracycline resistance in T. pyogenes isolates from European bison. These findings highlight that wild animals, including wild ruminants not treated with antimicrobials, can be a reservoir of tetracyclineresistant bacteria carrying resistance determinants, which may be easily spread among pathogenic and environmental microorganisms.

Keywords: antimicrobial resistance; European bison; livestock; tetracycline; tet genes; transposons; Trueperella pyogenes

\section{Introduction}

Trueperella pyogenes, a Gram-positive irregular rod, is a commensal of the mucus membranes of the upper respiratory, gastrointestinal and urogenital tracts of animals, and as well as an opportunistic pathogen [1,2]. This bacterium can cause different infections, such as mastitis, metritis, pneumonia or abscesses in various organs and tissues in a broad range of livestock, including swine, cattle, goats and sheep [3-6]. Likewise, T. pyogenes purulent infections were reported in dogs and cats [7-9]. In addition, infections associated with T. pyogenes were also described in various species of wild mammals [10-14] and reptiles [15]. However, diseases caused by T. pyogenes are economically important in cattle and swine because they lead to serious losses, including significant losses in milk production and 
reproduction and a reduction in meat quality $[6,16]$. Similar effects of T. pyogenes infections are also observed in small ruminant breeding [6]. In humans, T. pyogenes infections were rarely reported and were mostly associated with occupational exposure through contact with farm animals and their environment $[17,18]$.

Tetracyclines, broad-spectrum antibiotics, are frequently used as the first-choice drugs to prevent and treat human and animal infections, including T. pyogenes infections [6]. In addition, in some countries, these antimicrobials are still administrated as growth promoters in animal farming, especially poultry, cattle and swine $[19,20]$. Tetracycline, oxytetracycline, chlortetracycline and doxycycline are tetracyclines commonly applied in veterinary medicine $[21,22]$. Oxytetracycline is one of the antimicrobials most often used to treat clinical metritis. However, therapy with the long-acting oxytetracycline is not always a good choice for treatment metritis associated with T. pyogenes [23]. Currently, the wide use of tetracyclines is considered to be the main reason for increased antimicrobial resistance among Gram-negative and Gram-positive bacteria [24]. Importantly, the cross-resistance between different tetracyclines is noted. The resistance to tetracyclines is determined by several mechanisms that are supported by tetracycline resistance proteins known as Tet proteins. The most common tetracycline resistance mechanisms include an active efflux of drugs from the bacterial cell, ribosomal protection from drug action, and enzymatic inactivation of drugs $[21,24,25]$. Until now, 61 different tetracyclines resistance genes (tet) encoding Tet proteins, often associated with transposons or plasmids, have been characterized [24]. Due to the relation of the tet genes with mobile genetic elements, their distribution among strains, also belonging to different bacterial species, may be strongly widespread.

The tetracycline resistance in T. pyogenes was reported in several phenotypic studies, which referred mainly to isolates from cattle and swine [3,5,6,8,16,26-35]. In the case of isolates from wild animals, only limited data on the tetracycline resistance are available $[5,10]$. Moreover, genotypes of tetracycline resistance in T. pyogenes isolates of various origins are still poorly understood. Till now, two mechanisms of tetracycline resistance in T. pyogenes have been described, first associated with ribosomal protection proteins (RPPs) encoded by the tet $W$ or tet $M$ genes, and second relied on the activity of efflux pump proteins encoded by the tet $K$, tet $L$ or $t e t A(33)$ genes $[33,36,37]$. Importantly, different antimicrobial resistance genes in T. pyogenes, including tetracycline resistance genes, may be associated with transposons [37], plasmids [36] or integron gene cassettes [26,38].

Currently, there are no T. pyogenes-specific breakpoints for antimicrobial susceptibility testing available in the Clinical and Laboratory Standards Institute (CLSI) guidelines [39]. Hence, the resistance to antimicrobials commonly used against $T$. pyogenes infections, including tetracyclines, should be incessantly monitored, as obtained data would be important to define missing breakpoints for this bacterium. Thus, in this study, we investigated the prevalence of tetracycline resistance and the distribution and characterization of tetracycline resistance determinants among a large collection of $T$. pyogenes, isolates from different host species, including unique isolates from European bison (Bison bonasus).

\section{Results}

\subsection{Susceptibility to Tetracycline}

Among 114 tested T. pyogenes isolates from a different origin, 49 (43.0\%; CI 95\%: $34.3 \%, 52.2 \%$ ) were classified as resistant to tetracycline (MIC $\geq 8 \mu \mathrm{g} / \mathrm{mL}$ ), and the $\mathrm{MIC}_{50}$ and $\mathrm{MIC}_{90}$ values for all isolates were 4 and $32 \mu \mathrm{g} / \mathrm{mL}$, respectively. The distribution of tetracycline MIC values obtained for the studied isolates is presented in Table 1. The highest prevalence of tetracycline resistance was noted among the bovine isolates- $89.5 \%$ (34/38; CI 95\%: 75.9\%, 95.8\%). The $\mathrm{MIC}_{50}$ and $\mathrm{MIC}_{90}$ of tetracycline for bovine isolates had the same value, $32 \mu \mathrm{g} / \mathrm{mL}$. The significantly lower prevalence of tetracycline resistance was found in isolates from swine-33.3\% (9/27; CI 95\%: 18.6\%, 52.2\%; $p<0.001)$, European bison-16.7\% (5/30; CI 95\%: 7.3\%, 33.6\%; $p<0.001)$ and small ruminants-5.3\% $(1 / 19$; CI 95\%: $0.9 \%, 24.6 \% ; p<0.001)$. There was no significant difference in the prevalence of tetracycline 
resistance between swine and European bison isolates $(p=0.219)$, nor between European bison and small ruminant isolates $(p=0.384)$. However, the prevalence of tetracycline resistance was significantly lower in small ruminants than in swine isolates $(\mathrm{p}=0.031)$. The tetracycline $\mathrm{MIC}_{50}$ and $\mathrm{MIC}_{90}$ values for swine isolates were 4 and $8 \mu \mathrm{g} / \mathrm{mL}$, respectively. The $\mathrm{MIC}_{50}$ for caprine and European bison isolates was the same, $0.25 \mu \mathrm{g} / \mathrm{mL}$. However, the $\mathrm{MIC}_{90}$ value was different, $1 \mu \mathrm{g} / \mathrm{mL}$ for caprine isolates and $32 \mu \mathrm{g} / \mathrm{mL}$ for European bison isolates. Among small ruminant, T. pyogenes isolates, only one originated from a goat was resistant to tetracycline, while all ovine isolates were susceptible to the tested antibiotic, and the $\mathrm{MIC}_{50}$ and $\mathrm{MIC}_{90}$ values were $\leq 0.125 \mu \mathrm{g} / \mathrm{mL}$.

Table 1. Distribution of minimum inhibitory concentration (MIC) of tetracycline, $\mathrm{MIC}_{50}$ and $\mathrm{MIC}_{90}$ values for the studied Trueperella pyogenes isolates $(n=114)$.

\begin{tabular}{|c|c|c|c|c|c|c|c|c|c|c|c|c|c|}
\hline \multirow{2}{*}{ Isolate Origin } & \multicolumn{11}{|c|}{ Number of Isolates with the Indicated MIC $(\mu \mathrm{g} / \mathrm{mL})^{\mathrm{a}}$} & \multirow{2}{*}{$\mathrm{MIC}_{50}$} & \multirow{2}{*}{$\mathrm{MIC}_{90}$} \\
\hline & $\leq \mathbf{0 . 1 2 5}$ & 0.25 & 0.5 & 1 & 2 & 4 & 8 & 16 & 32 & 64 & $\geq 128$ & & \\
\hline Cattle & 1 & 1 & 2 & & & & 4 & 9 & 21 & & & 32 & 32 \\
\hline Swine & 1 & 3 & 1 & 1 & 1 & 11 & 6 & 2 & 1 & & & 4 & 8 \\
\hline Goat & 4 & 5 & 2 & 1 & & & 1 & & & & & 0.25 & 1 \\
\hline Sheep & 5 & & 1 & & & & & & & & & $\leq 0.125$ & $\leq 0.125$ \\
\hline European bison & 11 & 9 & 4 & & 1 & & & 1 & 4 & & & 0.25 & 32 \\
\hline Total & 22 & 18 & 10 & 2 & 2 & 11 & 11 & 12 & 26 & & & 4 & 32 \\
\hline
\end{tabular}

a MIC breakpoint for tetracycline used in this study: $\geq 8 \mu \mathrm{g} / \mathrm{mL}$. Resistant isolates are shaded.

\subsection{Prevalence of Tetracycline Resistance Genes}

The prevalence of selected tetracycline resistance genes was investigated for all tested T. pyogenes isolates $(n=114)$. The tetracycline resistance genotypes of $T$. pyogenes isolates are phenotypically classified as resistant (49/114), and the occurrence of resistance determinants among these isolates are summarized in Table 2. In 46 isolates out of 49 tetracycline-resistant isolates, the results of PCR with universal primer set indicated the presence of tetracycline resistance genes encoding RPPs. The RPPs genes were found in 32 bovines, nine swine and five European bison isolates. Then the presence of tet $W$, one of the more frequent genes encoding the tetracycline resistance RPPs, was studied by PCR using two different specific primer sets. In PCR with primers tetW_F and tetW_R, previously described [37], the positive result was obtained only for 38 isolates. In the case of 8 remaining isolates, amplicons obtained with universal primers were subjected to sequence analysis. Based on the analysis results, a new primer set for tet $W$ was designed. The use of tetW-all_F and tetW-all_R primers (designed in this study) allowed to detection of tet $W$ in all 46 T. pyogenes isolates, recognized previously as RPPs gene-positive with the universal primer set. Finally, it was confirmed that $46 / 114$ isolates $(40.4 \%$; CI $95 \%: 31.8 \%$, $49.5 \%$ ) carried the tet $W$ gene, including 32 of 38 bovine isolates ( $84.2 \%$; CI 95\%: $69.6 \%$, $92.6 \%$ ), nine of 27 swine isolates (33.3\%; CI 95\%: $18.6 \%, 52.2 \%$ ) and five of 30 European bison isolates (16.7\%; CI 95\%: 7.3\%, 33.6\%).

Among all T. pyogenes isolates 8.8\% (10/114; CI 95\%: 4.8\%, 15.4\%) carried the tet A(33) gene, including nine of 38 bovine isolates $(23.7 \%$; CI 95\%: $13.0 \%, 39.2 \%)$ and one of 13 caprine isolate $(7.7 \%$; CI 95\%: $1.4 \%, 33.3 \%)$. The prevalence of the tet $A(33)$ gene did not differ significantly between the bovine and caprine isolates $(p=0.419)$. Although, eight of the bovine isolates harbored both resistance genes, tet $A(33)$ and tet $W$. Other tested genes, tet $M$, tet $O$, tet $K$, and tet $L$, were not detected in the studied isolates.

Generally, genetic tetracycline resistance determinants were found in 48 out of 49 tetracycline-resistant isolates $(98.0 \%$; CI 95\%: 89.3\%, 99.6\%) that indicates the high accordance between the tetracycline resistance phenotype and genotype in the studied isolates (Table 2). Only one tetracycline-resistant bovine isolate (16/B), for which MIC was $8 \mu \mathrm{g} / \mathrm{mL}$, did not carry any of the tested tet genes. 
Table 2. Occurrence of the tet $W$ and tet $A(33)$ genes, tet $W-3$ linked to ATE- 1 transposon, and the tetracycline MIC values for the tetracycline-resistant Trueperella pyogenes isolates $(n=49)$. The presence of tet $W$ was tested using two different primer sets.

\begin{tabular}{|c|c|c|c|c|c|c|c|}
\hline \multirow{2}{*}{$\begin{array}{c}\text { Isolate } \\
\text { Designation }\end{array}$} & \multirow{2}{*}{ Isolate Origin } & \multicolumn{4}{|c|}{ Gene $^{a}$} & \multirow{2}{*}{$\begin{array}{l}\text { tetW-3 Linked } \\
\text { to ATE-1 }\end{array}$} & \multirow{2}{*}{$\operatorname{MIC}(\mu \mathrm{g} / \mathrm{mL})$} \\
\hline & & Tet $\mathbf{b}$ & tet $\mathrm{W}^{\mathrm{c}}$ & tet $W^{\mathrm{d}}$ & tetA(33) & & \\
\hline $2 / B$ & Bovine & + & + & + & + & + & 32 \\
\hline $4 / B$ & Bovine & + & + & + & + & + & 32 \\
\hline $5 / B$ & Bovine & + & + & + & - & + & 32 \\
\hline $6 / B$ & Bovine & + & + & + & - & + & 16 \\
\hline $7 / B$ & Bovine & + & + & + & + & + & 32 \\
\hline $8 / \mathrm{B}$ & Bovine & + & + & + & - & + & 32 \\
\hline $9 / B$ & Bovine & + & + & + & - & + & 16 \\
\hline $10 / \mathrm{B}$ & Bovine & + & + & + & - & + & 32 \\
\hline $11 / \mathrm{B}$ & Bovine & + & + & + & - & + & 16 \\
\hline $12 / \mathrm{B}$ & Bovine & + & + & + & - & + & 32 \\
\hline $14 / B$ & Bovine & + & + & + & - & + & 16 \\
\hline $15 / B$ & Bovine & - & - & - & + & - & 8 \\
\hline $16 / B$ & Bovine & - & - & - & - & - & 8 \\
\hline $18 / \mathrm{B}$ & Bovine & + & + & + & - & + & 32 \\
\hline $19 / B$ & Bovine & + & + & + & - & + & 32 \\
\hline $20 / B$ & Bovine & + & + & + & - & + & 32 \\
\hline $21 / B$ & Bovine & + & + & + & + & + & 32 \\
\hline $22 / B$ & Bovine & + & + & + & - & + & 32 \\
\hline $23 / B$ & Bovine & + & + & + & + & + & 32 \\
\hline $24 / B$ & Bovine & + & + & + & - & + & 32 \\
\hline $25 / B$ & Bovine & + & + & + & - & + & 32 \\
\hline $26 / B$ & Bovine & + & + & + & + & + & 16 \\
\hline $27 / B$ & Bovine & + & + & + & - & + & 32 \\
\hline $28 / B$ & Bovine & + & + & + & - & + & 32 \\
\hline $29 / B$ & Bovine & + & + & + & - & + & 16 \\
\hline $30 / B$ & Bovine & + & + & + & - & + & 16 \\
\hline $31 / B$ & Bovine & + & + & + & - & + & 16 \\
\hline $32 / B$ & Bovine & + & + & + & + & + & 32 \\
\hline $33 / B$ & Bovine & + & + & + & + & + & 32 \\
\hline $34 / B$ & Bovine & + & + & + & - & + & 8 \\
\hline $35 / B$ & Bovine & + & + & + & - & + & 32 \\
\hline $36 / B$ & Bovine & + & + & + & - & + & 16 \\
\hline $37 / \mathrm{B}$ & Bovine & + & + & + & - & + & 8 \\
\hline $38 / \mathrm{B}$ & Bovine & + & + & + & - & + & 32 \\
\hline $2 / S$ & Swine & + & - & + & - & - & 16 \\
\hline $8 / S$ & Swine & + & + & + & - & + & 32 \\
\hline $10 / S$ & Swine & + & - & + & - & - & 8 \\
\hline $11 / S$ & Swine & + & - & + & - & - & 8 \\
\hline $12 / S$ & Swine & + & - & + & - & - & 8 \\
\hline $14 / S$ & Swine & + & - & + & - & - & 8 \\
\hline $16 / S$ & Swine & + & - & + & - & - & 16 \\
\hline $17 / S$ & Swine & + & - & + & - & - & 8 \\
\hline $49 / S$ & Swine & + & - & + & - & - & 8 \\
\hline $3 / Z$ & European bison & + & + & + & - & + & 32 \\
\hline $7 / Z$ & European bison & + & + & + & - & + & 32 \\
\hline $8 / Z$ & European bison & + & + & + & - & + & 16 \\
\hline $10 / Z$ & European bison & + & + & + & - & + & 32 \\
\hline $14 / Z$ & European bison & + & + & + & - & + & 32 \\
\hline $6 / \mathrm{K}$ & Caprine & - & - & - & + & - & 8 \\
\hline
\end{tabular}

${ }^{a}+$ : presence of a gene; -: absence of a gene; ${ }^{b}$ gene detected using universal primers detecting tetracycline resistance genes encoding ribosome protection proteins; ${ }^{\mathrm{c}}$ gene detected using primers designed by Billington and Jost [37]; ${ }^{\mathrm{d}}$ gene detected using new primers designated in this study; ${ }^{\mathrm{e}}$ presence of $522 \mathrm{bp}$ fragment indicating the presence of tet $W-3$ linked to ATE- 1 transposon. 


\subsection{Sequence and Phylogenetic Analysis of the tet Genes}

The sequence analysis of PCR products obtained using the universal primer set for tetracycline resistance RPPs genes was performed for 15 isolates, including 8 isolates in which tet $W$ was not detected by PCR with the tet W primer set previously described [37], and 7 selected tet $W$-positive isolates confirmed by this reaction, used as controls of PCR specificity. The analysis showed that all amplicons should be identified as the tet $W$ gene. According to the BLASTN analysis, the tet $W$ sequences of six $T$. pyogenes swine isolates (10/S, 11/S, 12/S, 14/S, 17/S, 49/S) displayed 100\% identity to each other, as well as $99.89 \%$ identity to the tet $W-1$ gene of Butyrivibrio fibrisolvens (AJ427421.2). However, the tet $W$ nucleotide sequence of the $2 / \mathrm{S}$ isolate indicated $99.89 \%$ identity to tet W-2 of Megaspharea elsdenii (AY485124.1). A group of isolates, including two bovines (2/B, 26/B), one swine $(8 / S)$ and four isolates from European bison $(3 / Z, 8 / Z, 10 / Z, 14 / Z)$, contained tetW displaying $100 \%$ identity to the sequence of the $t e t W-3$ gene related to transposon ATE-1 from T. pyogenes (AY049983.2). However, the tet $W$ nucleotide sequence of the 16/S isolate showed $100 \%$ identity to the $t e t W-4$ gene associated with transposon ATE-2 from T. pyogenes (DQ517519.1).

The phylogenetic analysis showed that the sequences of tet $W$ differed in the studied $T$. pyogenes isolates (Figure 1). Thus, based on noticed diversity, those isolates may be divided into four groups carrying variable variants of the tet $\mathrm{W}$ gene, such as tet $\mathrm{W}-1$, tet $W-2$, tet $\mathrm{W}-3$ and tet $W-4$ (Figure 1). The swine T. pyogenes isolates carried four different variants of tet $W$, while bovine and European bison isolates possessed only tet W-3 (Figure 1).

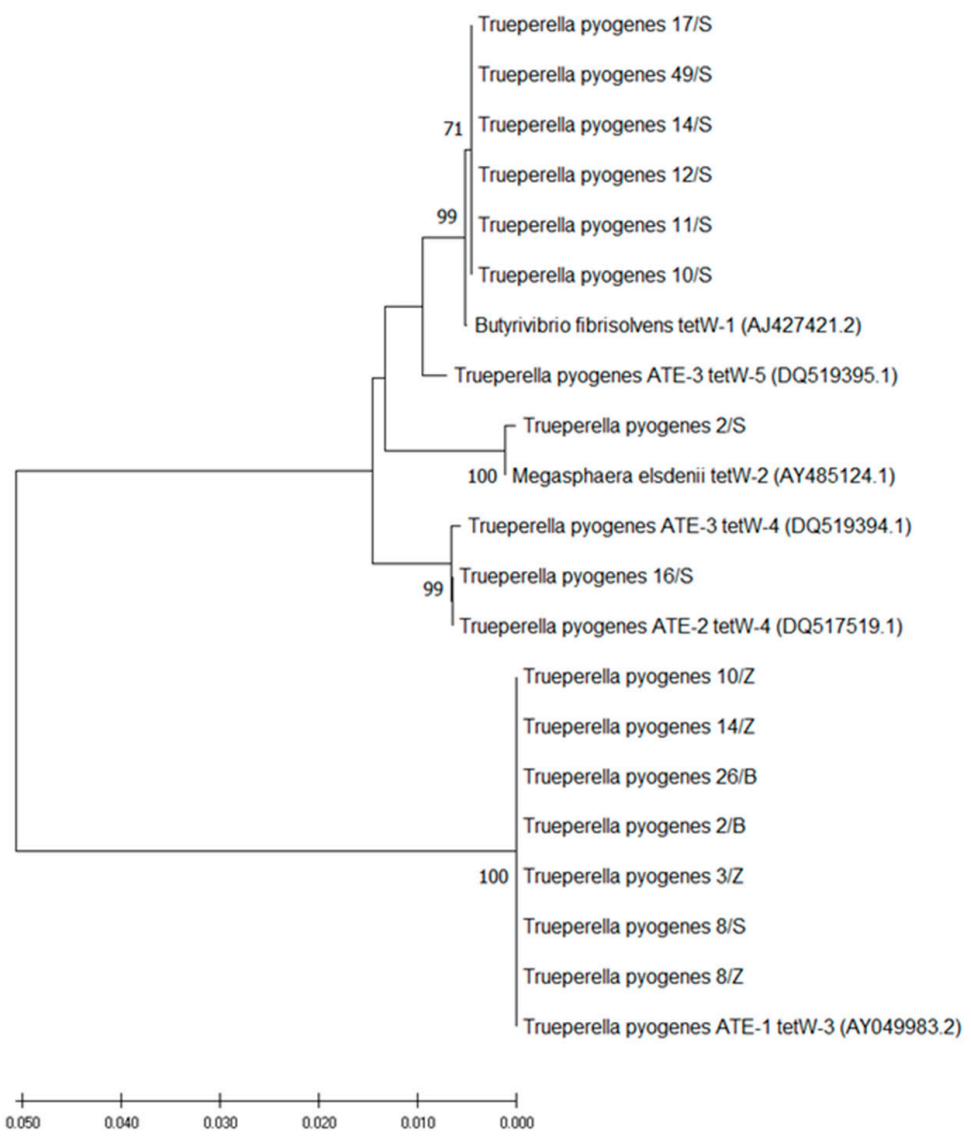

Figure 1. The phylogenetic tree based on a comparison of sequences (933 nucleotides) of the tet $W$ gene of 15 Trueperella pyogenes isolates from this study (2/B, 26/B, 3/Z, 8/Z, 10/Z, 14/Z, 2/S, 8/S, 10/S, $11 / \mathrm{S}, 12 / \mathrm{S}, 14 / \mathrm{S}, 16 / \mathrm{S}, 17 / \mathrm{S}, 49 / \mathrm{S})$ and the tet $W$ sequences of selected bacterial species retrieved from the GenBank database (accession numbers in parentheses). The tree was constructed by the neighbor-joining method. Bootstrap values (1000 replicates) of above $70 \%$ are shown. The scale bar represents the number of substitutions per site. 
Importantly, the nucleotide sequences differed among the reported tet $W$ variants in the studied isolates (Figure S1 of Supplementary Materials). Sequence analysis revealed that the $t e t W$ genes from European bison T. pyogenes isolates $(8 / \mathrm{Z}$ and $14 / \mathrm{Z})$ were $100 \%$ identity to each other and to the tet $W$ sequences previously described in this bacterium (NG_048284.1, AY049983.2). Moreover, tet $W$ from these T. pyogenes isolates shared $93.84 \%$ identity with tetW from Lawsonia intracellularis (NG_055990.1).

The nucleotide analysis of the tet $A$ (33) sequences from two selected bovine T. pyogenes isolates (2/B and $26 / \mathrm{B}$ ) revealed $100 \%$ identity with the tet $A(33)$ from $T$. pyogenes (AY255627.1) and Corynebacterium glutamicum (NG_048127.1). In addition, these genes shared 99.59\% identity with tetA(33) from Arthrobacter protophormiae (DQ077487.1).

\subsection{Occurrence of tetW-3 Linked to the ATE-1 Transposon Among T. pyogenes Isolates}

Based on the results of sequence analysis, tet $W-3$, a variant of the tet $W$ gene, was suspected to be the most prevalent tetracycline resistance determinant among studied $T$. pyogenes isolates. To confirm this observation, a presence of the $522 \mathrm{bp}$ fragment (tet $\mathrm{W}-3$ orf110) characteristic for the tet $W-3$ variant linked to the ATE- 1 transposon was investigated. The tet $W$-3 or f110 fragment was detected in 38 out of 46 tetracycline-resistant $T$. pyogenes isolates harboring tet $W$. All tet $W$-positive bovine $(n=32)$ and European bison $(n=5)$ isolates carried tet $\mathrm{W}-3$ linked to ATE-1 transposon (Table 2). However, these genetic elements were found only in one swine isolate out of nine carrying tet $W$. These findings indicate that tet $\mathrm{W}-3$, more important, associated with a mobile element, is the predominant tetracycline resistance determinant in $T$. pyogenes isolates from ruminants.

\section{Discussion}

In recent years, increasing antimicrobial resistance in bacteria of animal origin has become an important health and economic issue [40]. One of the well-recognized factors involved in the development of bacterial resistance is the overuse of antimicrobials in veterinary medicine [41]. The use of tetracyclines in food-producing animals in Europe is invariably higher compared to other antimicrobial classes [41]. According to the European Medicines Agency (EMA) tenth European Surveillance of Veterinary Antimicrobial Consumption (ESVAC) report, the sales of tetracyclines for food-producing animals in 2018 was the highest in Cyprus (155.2 mg/PCU) and the lowest in Norway $(0.1 \mathrm{mg} / \mathrm{PCU})$, while in Poland it was $47.3 \mathrm{mg} / \mathrm{PCU}$ [41]. In Poland, tetracyclines are widely used in livestock, especially in cattle and swine [42]. However, recently, an increase in tetracycline consumption in horses has been observed as well [42]. Moreover, these antimicrobials can also be found in medicinal feeds used for animals [22]. It should be highlighted that widespread use of tetracyclines in animals may lead to significant dissemination of bacteria resistant to these antimicrobials and to environmental accumulation of resistance determinants $[43,44]$. This problem also concerns the treatment of infections caused by T. pyogenes in livestock, mainly in cattle, for which tetracyclines are often used. Thus, in the present study, we investigated the tetracycline resistance mechanisms among T. pyogenes isolates of different origins, concerning unique isolates from European bison. Importantly, resistance genotypes and phenotypes were compared to obtain data important for further research on establishing tetracycline breakpoints specific for T. pyogenes.

Discussing the results of antimicrobial susceptibility testing should consider methodological differences may cause some interpretation inconsistencies. In the case of many studies, T. pyogenes isolates for which a tetracycline MIC was $8 \mu \mathrm{g} / \mathrm{mL}$ or higher were classified as resistant, like in our work $[10,26,27,29,33]$.

In the present study, the high prevalence of tetracycline resistance $(89.5 \%)$ in bovine T. pyogenes isolates ( $\mathrm{MIC}_{90}=32 \mu \mathrm{g} / \mathrm{mL}$ ) was reported. A similar observation was noted by Zastempowska, and Lassa [28] for T. pyogenes isolates from bovine mastitis, also collected in Poland, among which $85.5 \%$ were reported as resistant to tetracycline. In Iran, the tetracycline resistance of $T$. pyogenes isolated from bovine mastitis and metritis ranges from $10.8 \%$ to $97.8 \%$ [32,34,35]. Similarly, in China, $70.0 \%$ of $T$. pyogenes isolates from bovine 
mastitis were tetracycline-resistant [31]. In this country, the high-frequency of resistance to tetracycline $(68.8 \%)$, oxytetracycline $(53.1 \%)$ and doxycycline $(62.5 \%)$ was also shown in T. pyogenes isolates from bovine endometritis $[26,33]$. The high percentage, over the range from $41.7 \%$ to $54.2 \%$, of tetracycline, chlortetracycline and oxytetracycline-resistant T. pyogenes isolates of bovine origin was noted in the United States $[8,27]$. Moreover, Ozturk et al. [30] reported $84.1 \%$ of bovine T. pyogenes strains isolated in Turkey as resistant to oxytetracycline. However, the $\mathrm{MIC}_{90}$ values of tetracycline, chlortetracycline, oxytetracycline, doxycycline and metacycline determined for T. pyogenes isolates from bovine endometritis in China, were $32 \mu \mathrm{g} / \mathrm{mL}, 16 \mu \mathrm{g} / \mathrm{mL}, 32 \mu \mathrm{g} / \mathrm{mL}, 16 \mu \mathrm{g} / \mathrm{mL}$, and $8 \mu \mathrm{g} / \mathrm{mL}$, respectively [33]. In Europe, the highest tetracycline $\mathrm{MIC}_{90}(64 \mu \mathrm{g} / \mathrm{mL})$ was reported for bovine T. pyogenes isolates in Spain and Germany [6,45].

The tetracycline resistance at a relatively lower level has been noted for swine T. pyogenes isolates. In this study, 33.3\% of swine isolates were classified as resistant to tetracycline, and $\mathrm{MIC}_{90}$ was $8 \mu \mathrm{g} / \mathrm{mL}$. A similar rate of tetracycline-resistant swine T. pyogenes isolates, $41.7 \%$, was found in the United States [8]. Furthermore, $\mathrm{MIC}_{90}$ determined for swine T. pyogenes isolated in Spain was $16 \mu \mathrm{g} / \mathrm{mL}$ [16]. Although, in some cases, higher tetracycline $\mathrm{MIC}_{50}$ values were reported for swine T. pyogenes isolates comparing to bovine ones, e.g., in the study of Yoshimura et al. [3], chlortetracycline $\mathrm{MIC}_{50}$ was $12.5 \mu \mathrm{g} / \mathrm{mL}$ for swine isolates and $6.25 \mu \mathrm{g} / \mathrm{mL}$ for bovine isolates. Differences in the consumption of tetracyclines used for the treatment of infections in swine and cattle seem to be one of the possible reasons for the observed divergence in a level of tetracycline resistance [8].

The resistance to tetracyclines in T. pyogenes isolated from small ruminants has been poorly examined to date. In the present study, we noted a low percentage of tetracyclineresistant caprine T. pyogenes isolates $(7.7 \%)$, whereas all isolates from sheep were tetracyclinesusceptible. These results confirmed the observations of Galán-Relaño et al. [6] that showed a relatively low prevalence of tetracycline-resistant T. pyogenes strains isolated from small ruminants in Spain. However, they demonstrated significantly higher tetracycline $\mathrm{MIC}_{90}$ values $(16 \mu \mathrm{g} / \mathrm{mL}$ for caprine isolates and $8 \mu \mathrm{g} / \mathrm{mL}$ for ovine isolates) than that reported in our study $(1 \mu \mathrm{g} / \mathrm{mL}$ for caprine isolates and $\leq 0.125 \mu \mathrm{g} / \mathrm{mL}$ for ovine isolates) [6]. Moreover, Fernández et al. [46] also reported the high MICs of tetracycline $(16 \mu \mathrm{g} / \mathrm{mL})$ for all tested T. pyogenes isolates from sheep in Spain.

It might seem that wild animals living in the environment with no antibiotic pressure are not a reservoir of antimicrobial-resistant bacteria. However, in our study, we demonstrated that wild ruminants, such as European bison, might be infected with tetracyclineresistant T. pyogenes strains. Admittedly, the rate of tetracycline-resistant isolates from those wild animals was relatively low $(16.7 \%)$ but concurrently higher than that for isolates from goats or sheep. Interestingly, $\mathrm{MIC}_{90}$ of tetracycline for European bison isolates was the same as obtained for bovine isolates, although $\mathrm{MIC}_{50}$ was higher for bovine origin isolates. It should be highlighted that T. pyogenes isolates were collected from European bison never treated with any antimicrobials, thus in this case, an effect of selective pressure could be excluded. Our observations suggest a possibility of infection of those wild ruminants by T. pyogenes strains of bovine origin. The fact that European bison may use the agricultural land and the same grassland as cattle strongly indicates that transmission of resistant bacteria may occur among livestock and wild animals $[47,48]$. On the other hand, the fact that tetracycline resistance determinants can be acquired by T. pyogenes from other bacteria should also be considered. Similar observations concerning the tetracycline resistance in T. pyogenes that occurred in wild herbivores were previously noted for isolates from farmed white-tailed deer (Odocoileus virginianus) [10,49]. The occurrence of T. pyogenes isolates from cases of pneumonia in this animal species, resistant to chlortetracycline (48.3\%) and oxytetracycline $(31.0 \%)$, was reported. Moreover, $\mathrm{MIC}_{90}$ values of these antimicrobials were relatively high, $8 \mu \mathrm{g} / \mathrm{mL}$ and $16 \mu \mathrm{g} / \mathrm{mL}$ for chlortetracycline and oxytetracycline, respectively [10]. Conversely, the lower $\mathrm{MIC}_{90}(0.19 \mu \mathrm{g} / \mathrm{mL})$ of tetracycline was reported for T. pyogenes isolates from cases of necrobacillosis in white-tailed deer [49]. 
Although the T. pyogenes resistance to tetracyclines has been widely reported, its genetic determinants were not well described. Our study showed that the tetracycline resistance in T. pyogenes was mainly associated with the presence of the tet $W$ gene. This gene encodes TetW, one of the ribosomal protection proteins associated with tetracycline resistance [50]. The tet $W$ gene was previously identified in many microorganisms, among others in anaerobic bacteria isolated from bovine and sheep rumen, swine feces and human fecal biota [51-55]. In the present study, tetW was detected in $40.4 \%$ of T. pyogenes isolates, mainly swine and bovine, classified as resistant, for which the tetracycline MIC values ranged from 8 to $32 \mu \mathrm{g} / \mathrm{mL}$. Interestingly, Zastempowska and Lassa [28] found the tet $W$ gene in all studied bovine T. pyogenes isolates from mastitis with the tetracycline MICs greater or equal $4 \mu \mathrm{g} / \mathrm{mL}$. Generally, the presence of $t e t W$ in tetracycline-susceptible bacteria has been rarely reported [55]. In the study of Billington et al. [56], the tet $W$ gene was the most prevalent in bovine, swine, and macaw T. pyogenes isolates resistant to tetracycline, chlortetracycline and oxytetracycline. The presence of this gene among bovine T. pyogenes isolates resistant to different tetracyclines was also reported in other studies [33-35]. Thus, the Tet $\mathrm{W}$ protein probably determines resistance to various antimicrobials belonging to the class of tetracyclines. Until now, the data on the occurrence of the tet $W$ gene among T. pyogenes isolates from wild animals were limited. Only in the case of three T. pyogenes isolates from gray slender lorises kept at Zoo, the presence of tet $W$ was reported [14]. Moreover, the presence of this gene was also reported in one tetracycline-resistant T. pyogenes to isolate from birds [56]. Surprisingly, in our study, a significant percentage of the European bison T. pyogenes isolates carried the tet $W$ gene as the main tetracycline resistance determinant. To the best of our knowledge, this is the first report on the prevalence of this gene in T. pyogenes isolates from European bison.

The differentiation of the tet $W$ gene sequences was observed in various bacterial species, such as Megasphera elsdenii [53] or Bifidobacterium spp. [55,57]. Although, a detailed analysis of the $t e t W$ sequence has been rarely performed, and the variants of this gene the most often were not determined. Billington and Jost [37] described different sequence variants of the tet $W$ gene, including tet $W-1$, tet $W-3$, tet $W-4$ and tet $W-5$, found in T. pyogenes. Similarly, in the studied T. pyogenes isolates of various origin, we detected tet $W-1$, tet $W-3$ and tet $W-4$ variants of tet $W$. Importantly, in one swine isolate, we found the tet $W-2$ variant, which was not previously reported in T. pyogenes. In this study, the tet $W-1$ and tet $W-4$ variants were related only to the swine isolates. However, tet $W-3$ was found in swine, bovine and European bison isolates. In contrast, Billington and Jost [37] identified this variant of tet $W$ only in bovine isolates. Thus, this is the first description of the tet $W-3$ variant occurring in swine and European bison T. pyogenes isolates.

Importantly, it was showed that the flanking regions of tet $W$ might have different sequences [54,55]. Therefore, a multiple nucleotide sequence alignment analysis was done for selected variants of the tet $W$ gene, and the results are presented in Figure S1 of Supplementary Materials. As we suspected, some differences in the sequences of flanking regions of $t e t W-1$ and $t e t W-3$ were detected. This finding may explain false-negative results obtained for several isolates by PCR using the previously described primer set [37]. Since the reverse primer (tetW_R) sequence corresponds to the variable flanking region of $t e t W$, this gene may not be detected in some tetracycline-resistant $T$. pyogenes isolates. The same problem was noted by Villedieu et al. [57] in a case of some tetracycline-resistant isolates of oral bacteria tested for the tet $W$ presence by PCR using described primers. Therefore, in this study, we designed new primers specific for tet $W$, which link to the sequences inside this gene. The proposed primer set allows for the successful detection of all analyzed variants of the $t e t W$ gene. Nevertheless, all potential differences between sequences of tet $W$ variants, especially of flanking regions, should be considered during the phylogenetic analysis of tet $W$ relationships. Generally, our observations suggest that the studied T. pyogenes isolates might probably acquire the tet $W$ gene from different bacterial species.

It is known that the tet $W$ gene in T. pyogenes may be carried by different transposons, ATE-1, ATE-2 or ATE-3, usually depending on a variant of tetW [37]. In this study, the 
ATE-1 transposon was the most prevalent mobile genetic element related to the tet $W$ gene in T. pyogenes. The tet $W-3$ variant linked to ATE- 1 was found mainly in bovine and European bison isolates and in one swine isolate. In a single swine isolate, we found another transposon, ATE-2, carrying tet $W-4$, which was not previously noted in swine T. pyogenes. It is the first report on the occurrence of ATE- 1 and ATE- 2 transposons in T. pyogenes of swine origin. The remaining swine isolates in this study contained tet $W-1$, which is not connected to any known transposons in T. pyogenes. Interestingly, the tet $W-3$ gene found in European bison T. pyogenes isolates were linked to ATE-1 like in the bovine isolates. This observation also indicates the potential relationship between T. pyogenes isolates from cattle and European bison. Moreover, it seems that ATE- 1 is a crucial genetic element involved in the widespread distribution of tetracycline resistance determinants among T. pyogenes strains that occurred in ruminants. However, the ATE-3 transposon was not detected in our study. The absence of ATE-3, which is frequently associated with the streptomycin resistance $a a d E$ gene [37], was not surprising as this gene was not found in the collection of T. pyogenes isolates in our previous investigation [38].

In the present study, we also tested the presence of two genes, tet $M$ and tet $O$, encoding tetracycline resistance RPPs, TetM and TetO, respectively. Nevertheless, any of those genes were not found in the tested T. pyogenes isolates. On the contrary, tet $M$ was detected in T. pyogenes isolates from bovine endometritis by Zhang et al. [33], while the absence of tetO was consistent with our results.

Another tetracycline resistance determinant revealed in the studied T. pyogenes isolates was tet $A(33)$. This gene encodes the tetracycline-specific efflux pump protein-TetA(33), a member of the major facilitator superfamily (MFS) of efflux pumps [36]. TetA(33) was previously described in Corynebacterium glutamicum as one of two repressor-regulated tetracycline resistance determinants of efflux systems in Gram-positive bacteria [58]. The presence of the tet $A(33)$ gene was demonstrated in T. pyogenes for the first time by Jost et al. [36]. Additionally, this gene can be found in some whole-genome sequences of T. pyogenes deposited in the GenBank database (CP033904.1, CP029004.1, CP029001.1). Our results indicated the relatively low prevalence $(8.8 \%)$ of the $\operatorname{tet} A(33)$ gene among the studied T. pyogenes isolates. This gene was detected in tetracycline-resistant, mainly bovine and single caprine isolates. To the best of our knowledge, this gene was not previously reported in T. pyogenes isolated from goat. It is worth noting that in the case of two isolates, in which tet $A(33)$ was the only gene related to the tetracycline resistance phenotype, the MIC of tetracycline was $8 \mu \mathrm{g} / \mathrm{mL}$. However, for T. pyogenes isolates harboring two tetracycline resistance genes, tet $W$ and tet $A(33)$, the MIC of tetracycline ranged from 16 to $32 \mu \mathrm{g} / \mathrm{mL}$. The tet $A$ (33) gene in C. glutamicum and T. pyogenes is associated with the insertion sequence IS6100 located in a plasmid, pTET3 or pAP2, respectively [36,58]. Additionally, the pAP2 plasmid of T. pyogenes may also contain, except tet $A(33)$, a macrolide resistance determinanterm $X$, whereas a presence of both those genes is not closely related [36]. Surprisingly, tetA(33) associated with IS6100 located in the T. pyogenes chromosomal DNA was also reported [59].

Moreover, in our study, we investigated the presence of two other genes, tet $K$ and tet $L$, encoding proteins associated with the efflux pump mechanism in T. pyogenes. The presence of both these genes in bovine T. pyogenes isolates was previously reported by Zhang et al. [33], but they were not detected in this study.

There are still limited data concerning antimicrobials' destiny in the environment and their effect on the development and emergence of antimicrobial resistance in bacteria. It is well-known that the overuse of antimicrobials in agriculture may lead to an increased selection of resistant strains [60]. However, it seems that one of the essential reasons for a high prevalence of antimicrobial resistance genes in the environment may be the horizontal transfer of these genes from fecal microbiota of livestock to environmental bacteria [61,62]. The tet $W$ gene, the most widespread tetracycline resistance determinant in bacteria of different origins, may be a good example of disseminating resistance genes among clinical and environmental strains. The occurrence of tet $W$ in soil and water samples 
nearby of swine and cattle farms is evidence of the persistence of resistance genes in the various environment, including wildlife [52,61,63-65]. Our findings obtained for T. pyogenes isolated from European bison also confirmed the easy spread of tet $W$ among strains that occurred in wild ruminants.

\section{Materials and Methods}

\subsection{Bacterial Isolates and Culture Conditions}

A total of 114 T. pyogenes isolates from livestock (38 from cattle, 27 from swine, 13 from goats, six from sheep) and free-living or captive European bison $(n=30)$ in Poland were studied. Clinical specimens were obtained from animals with different types of infections: purulent lesions or abscesses in various tissues (two from cattle, 13 from goats, seven from swine, six from sheep, 12 from European bison), pneumonia (20 from swine, three from European bison), mastitis (26 from cattle), metritis (10 from cattle) and balanoposthitis (15 from European bison). Bacteria were cultured on Columbia Agar supplemented with 5\% sheep blood (CAB) (Graso Biotech, Starogard Gdański, Poland) at $37{ }^{\circ} \mathrm{C}$ in $5 \% \mathrm{CO}_{2}$ atmosphere for $48 \mathrm{~h}$. T. pyogenes isolates were identified based on the phenotypic properties [5,11]. Additionally, the species-specific pyolysin gene (plo) was detected. The sequence of primers and PCR cycling conditions used for plo detection are presented in Table 3. The majority of isolates used in this study $(n=95)$ were identified previously $[5,11]$. The remaining isolates characterized in this investigation $(n=19)$ are described in Table S1 of Supplementary Materials.

Table 3. Primers and PCR conditions used in this study.

\begin{tabular}{|c|c|c|c|c|c|}
\hline $\begin{array}{c}\text { Primer } \\
\text { Designation }\end{array}$ & Primer Sequence $\left(5^{\prime}-3^{\prime}\right)$ & Target Gene & $\begin{array}{c}\text { Annealing } \\
\text { Temperature } \\
\left({ }^{\circ} \mathrm{C}\right)\end{array}$ & $\begin{array}{l}\text { Amplicon } \\
\text { Size (bp) }\end{array}$ & Reference \\
\hline $\begin{array}{l}\text { plo_F } \\
\text { plo_R }\end{array}$ & $\begin{array}{c}\text { TCATCAACAATCCCACGAAGAG } \\
\text { TTGCCTCCAGTTGACGCTTT }\end{array}$ & plo & $60^{b}$ & 150 & {$[27]$} \\
\hline $\begin{array}{l}\text { DI_F } \\
\text { DII_R }\end{array}$ & $\begin{array}{l}\text { GAYACICCIGGICAYRTIGAYTT } \\
\text { GCCCARWAIGGRTTIGGIGGIACYTC }\end{array}$ & tet $t^{a}$ & $53^{b}$ & 1100 & [66] \\
\hline $\begin{array}{l}\text { TKI_F } \\
\text { TL32_R }\end{array}$ & $\begin{array}{l}\text { CCTGTTCCCTCTGATAAA } \\
\text { CAAACTGGGTGAACACAG }\end{array}$ & $\begin{array}{l}\text { tetK/ } \\
\text { tetL }\end{array}$ & $50^{b}$ & 1050 & {$[67]$} \\
\hline $\begin{array}{l}\text { tetW_F } \\
\text { tetW_R }\end{array}$ & $\begin{array}{l}\text { GACAACGAGAACGGACACTATG } \\
\text { CGCAATAGCCAGCAATGAACGC }\end{array}$ & tet $W$ & $58^{\mathrm{b}}$ & 1843 & [37] \\
\hline $\begin{array}{l}\text { tetM_F } \\
\text { tetM_R }\end{array}$ & $\begin{array}{l}\text { TTAAATAGTGTTCTTGGAG } \\
\text { CTAAGATATGGCTCTAACAA }\end{array}$ & tet $M$ & $54^{c}$ & 656 & [68] \\
\hline $\begin{array}{l}\operatorname{tet} A(33) \_F \\
\operatorname{tet} A(33) \_R\end{array}$ & $\begin{array}{l}\text { GATGCCGATTCTTCCCGCACTGC } \\
\text { CCACGCATGATGAGAATCACGC }\end{array}$ & tet $A(33)$ & $58^{b}$ & 1089 & {$[36]$} \\
\hline $\begin{array}{l}\text { tetO_F } \\
\text { tetO_R }\end{array}$ & $\begin{array}{c}\text { GGCGTTTTGTTTATGTGCG } \\
\text { ATGGACAACCCGACAGAAGC }\end{array}$ & tetO & $50^{c}$ & 559 & [69] \\
\hline $\begin{array}{l}\text { tetK_F } \\
\text { tetK_R }\end{array}$ & $\begin{array}{l}\text { TATTTGGCTTTGTATTCTTTCAT } \\
\text { GCTATACCTGTTCCCTCTGATAA }\end{array}$ & tet $K$ & $50^{b}$ & 1159 & {$[70]$} \\
\hline $\begin{array}{l}\text { tetL_F } \\
\text { tetL_R }\end{array}$ & $\begin{array}{l}\text { ATAAATTGTTTCGGGTCGGAAT } \\
\text { AACCAGCCAACTAATGACAATGAT }\end{array}$ & tet $L$ & $50^{b}$ & 1077 & {$[70]$} \\
\hline $\begin{array}{l}\text { ATE-1_F } \\
\text { ATE-1_R }\end{array}$ & $\begin{array}{l}\text { TGCCTGGCAGCGTCCGTCCGTG } \\
\text { AGGGCCAAGACCGCCGAGTTCC }\end{array}$ & tetW-3-orf110 & $55^{c}$ & 522 & [37] \\
\hline $\begin{array}{l}\text { tetW-all_F } \\
\text { tetW-all_R }\end{array}$ & $\begin{array}{l}\text { GTCTGTTCGGGATAAGCTCT } \\
\text { TGGAATACGCATCTCTGTGA }\end{array}$ & tet $W$ & $54^{c}$ & 466 & $\begin{array}{l}\text { This } \\
\text { study }\end{array}$ \\
\hline
\end{tabular}

${ }^{a}$ Universal primers detecting the tetracycline resistance genes encoding ribosome protection proteins; ${ }^{\mathrm{b}}$ PCR conditions: initial denaturation at $95^{\circ} \mathrm{C}$ for $3 \mathrm{~min} ; 35$ cycles of denaturation at $95^{\circ} \mathrm{C}$ for $1 \mathrm{~min}$, annealing for $1 \mathrm{~min}$ at variable temperatures and extension at $72{ }^{\circ} \mathrm{C}$ for $2 \mathrm{~min}$; a final extension at $72{ }^{\circ} \mathrm{C}$ for $5 \mathrm{~min} ;{ }^{\mathrm{C}} \mathrm{PCR}$ conditions: initial denaturation at $95^{\circ} \mathrm{C}$ for $3 \mathrm{~min} ; 30 \mathrm{cycles}$ of denaturation at $95{ }^{\circ} \mathrm{C}$ for $45 \mathrm{sec}$, annealing for $45 \mathrm{sec}$ at variable temperatures and extension at $72{ }^{\circ} \mathrm{C}$ for $1 \mathrm{~min}$; a final extension at $72{ }^{\circ} \mathrm{C}$ for $2 \mathrm{~min}$.

Four reference strains, T. pyogenes ATCC ${ }^{\circledR} 19411$, T. pyogenes ATCC ${ }^{\circledR} 49698$, Escherichia coli ATCC ${ }^{\circledR} 25922$ and Staphylococcus aureus ATCC $^{\circledR} 25923$, were included as controls for antimicrobial susceptibility testing. 


\subsection{Tetracycline Susceptibility Testing}

Antimicrobial susceptibility for 95 of the studied isolates was previously carried out by the strip diffusion method using Etest ${ }^{\circledR}$ strips [5]. In this study, tetracycline susceptibility testing for all $114 \mathrm{~T}$. pyogenes isolates was performed by the standard microdilution method according to the CLSI guidelines [71]. The bacterial inoculum (approximately $4 \times 10^{5} \mathrm{CFU} / \mathrm{mL}$ ) was prepared in Mueller-Hinton broth (Difco, Franklin Lakes, NJ, USA) containing 5\% (v/v) fetal calf serum (Graso Biotech, Starogard Gdański, Poland), and 100 $\mu \mathrm{L}$ of the inoculum was added into 96 wells of a microtiter plate. Double serial dilutions of tetracycline (Sigma-Aldrich, Steinheim, Germany) were performed in Mueller-Hinton broth (Difco, Franklin Lakes, New Jersey, USA) containing 5\% $(v / v)$ fetal calf serum (Graso Biotech, Starogard Gdański, Poland) and then $100 \mu \mathrm{L}$ of each dilution was added into the respective well, to receive a final tetracycline concentration over the range $128 \mu \mathrm{g} / \mathrm{mL}$ to $0.125 \mu \mathrm{g} / \mathrm{mL}$. Microtiter plates were incubated at $37{ }^{\circ} \mathrm{C}$ in a $5 \% \mathrm{CO}_{2}$ atmosphere for $24 \mathrm{~h}$. A MIC value was recorded as the lowest concentration of tetracycline that visibly inhibited bacterial growth. In addition, tetracycline concentrations required to inhibit the growth of $50 \%$ and $90 \%$ of isolates ( $\mathrm{MIC}_{50}$ and $\mathrm{MIC}_{90}$, respectively) were also determined. In the current CLSI guidelines, VET06 and VET08, there are no available tetracycline breakpoints specific for T. pyogenes [39,72]. Thus, MIC breakpoints used in this study to classify isolates as susceptible $(\leq 4 \mu \mathrm{g} / \mathrm{mL})$ or resistant $(\geq 16 \mu \mathrm{g} / \mathrm{mL}$, also included intermediate, $8 \mu \mathrm{g} / \mathrm{mL})$ to tetracycline were based on the interpretative criteria recommended for Corynebacterium spp. and coryneforms according to the CLSI guidelines [39].

\subsection{DNA Extraction}

A simple boiling method was used for DNA extraction from the tested T. pyogenes isolates. Briefly, several colonies from a $48 \mathrm{~h}$ culture of an isolate on $\mathrm{CAB}$ were suspended in $500 \mu \mathrm{L}$ of nuclease-free water. The suspension was heated at $99^{\circ} \mathrm{C}$ for $10 \mathrm{~min}$, cooled on ice and centrifuged $(6 \mathrm{~min}, 10,500 \times g)$. The supernatant was collected and stored at $-20{ }^{\circ} \mathrm{C}$ until further use.

\subsection{Detection of Tetracycline Resistance Genes}

The presence of genes associated with the tetracycline resistance was examined by standard PCR using universal primers for different tet genes encoding RPPs, primers specific for both the tet $K$ and tet $L$ genes, and the primer sets for detecting genes encoding particular tetracycline resistance determinants, such as tet $W$, tet $M$, tet $O$, tet $A(33)$, tet $K$, and tet $L$ (Table 3). The tet $W$, tet $M$ and tet $O$ genes are associated with the ribosomal protection mechanism, while tet $K$, tet $L$ and tet $A(33)$ with the efflux pump mechanism. Two various pairs of primers were used for tet $W$ detection (Table 3 ). All PCR reactions were performed in a $25 \mu \mathrm{L}$ reaction mixture containing DreamTaq master mix (2X) (Thermo Fisher Scientific, Waltham, MA, USA), nuclease-free water (Thermo Fisher Scientific, Waltham, MA, USA), 10 pmol of each primer (Genomed, Warsaw, Poland) and 70-90 ng of a template DNA. The thermal cycling conditions are presented in Table 3. Reaction products were recognized by electrophoresis ( $85 \mathrm{~V}$ by $45 \mathrm{~min})$ in $1 \%(w / v)$ agarose gel in TAE buffer with Midori green DNA stain (Nippon Genetics, Düren, Germany), visualized and analyzed using a VersaDoc Model 1000 imaging system and Quantity One software (version 4.4.0) (Bio-Rad, Hercules, CA, USA). DNA obtained from the clinical isolates, Enterococcus faecium TR2 and Lactobacillus acidophilus 2499, was used as a positive control in the PCR reactions for tetM and tet $K$, respectively. DNA from T. pyogenes $2 / \mathrm{B}$ and 26/B isolates, after sequencing of PCR products, was applied as a positive control for tet $W$ and tet $A$ (33) PCR, respectively. The $p$ Vir plasmid of Campylobacter jejuni was a positive control for the tetO detection.

\subsection{Sequencing and Phylogenetic Analysis}

The selected amplicons obtained with universal primers for tet genes encoding RPPs, as well as with primers specific for the tet $W$ and tet $A$ (33) genes, were sequenced (Genomed, Warsaw, Poland) in order to confirm the specificity of reactions. In cases of T. pyogenes 
isolates positive in PCR with universal DI_F and DII_R primers, but negative in PCR with primers tetW_F and tetW_R as well with primers specific for other tested genes, the amplicons obtained with the universal primer set were sequenced in order to establish a type of the tet gene. All sequencing files were evaluated using the Chromas 2.6.5 software (http:/ / www.technelysium.com.au/chromas.html, accessed on 15 February 2021). Subsequently, the obtained nucleotide sequences were compared with the sequences available in the GenBank database using the nucleotide BLAST program carried out on the National Center for Biotechnology Information (NCBI) website (http:/ / blast.ncbi.nlm.nih.gov, accessed on 15 February 2021) [73]. The alignment was performed using the multiple sequence alignment program Clustal Omega (https:/ /www.ebi.ac.uk/Tools/msa/clustalo/, accessed on 15 February 2021). A phylogenetic analysis was performed for selected isolates based on the sequences of the tet $W$ gene obtained by PCR with universal primers. The phylogenetic tree was constructed using the neighbor-joining method [74,75] in MEGA X [76]. The reliability of the tree was evaluated by the bootstrap method with 1000 replications [77].

\subsection{Detection of tetW-3 Linkage with the ATE-1 T. pyogenes Transposon}

A linkage of tet $W-3$, one of the variants of the tet $W$ gene, with the ATE- 1 transposon was studied by amplification of the $522 \mathrm{bp}$ DNA fragment extending from downstream of tetW-3 (covered region: 260-281 bp of tetW-3) into orf110 (covered region: $97-118 \mathrm{bp}$ of orf110) of the ATE-1 transposon, according to Billington and Jost [37]. The PCR using ATE-1_F and ATE-1_R primers, in conditions presented in Table 3, was performed for all tetracycline-resistant $T$. pyogenes isolates.

\subsection{Developing of New Primers for tetW Detection}

A new primer set was developed to detect the tet $W$ gene regardless of its variant. The primers tetW-all_F and tetW-all_R were designed using the Primer-Blast (https: / / www. ncbi.nlm.nih.gov/tools / primer-blast/, accessed on 15 February 2021) and checked using an Oligo Analysis Tool (https:/ / www.eurofinsgenomics.eu/en/ecom/tools/oligo-analysis/, accessed on 15 February 2021).

\subsection{Nucleotide Sequence Accession Numbers}

The nucleotide sequence of the tet $W$ gene from T. pyogenes European bison isolate $(8 / Z)$ from this study was deposited in GenBank under accession number MT798857. Furthermore, the sequence of the tet $A(33)$ gene from the bovine T. pyogenes isolate $(26 / \mathrm{B})$ was also deposited in GenBank under accession number MT798858.

\subsection{Statistical Analysis}

Categorical variables were presented as a count and frequency in a group and compared between groups using the two-tailed Fisher's exact test. The Wilson score method was used to calculate $95 \%$ confidence intervals (CI 95\%) for percentages. A significance level $(\alpha)$ was set at 0.05. Statistical analysis was performed in TIBCO Statistica 13.3.0 (TIBCO Software Inc., Palo Alto, CA, USA).

\section{Conclusions}

The present study provides significant data about the tetracycline resistance mechanisms among T. pyogenes isolates from livestock and European bison. Our findings suggest that not only bovine and swine T. pyogenes isolates, but also strains prevalent in wildlife may be a source of the tetracycline resistance genes. Moreover, it was confirmed that two main resistance mechanisms: one associated with ribosomal protection proteins encoded by different variants of the tet $W$ gene linked to the ATE- 1 or ATE- 2 transposons, and another related to active efflux pump proteins encoded by the tet $A(33)$ gene, determine resistance to tetracycline in T. pyogenes. Both mentioned genes may be acquired. However, the tet $W$ gene is the most prevalent tetracycline resistance determinant in this bacterium. Most importantly, the presence of tetW among T. pyogenes isolates from European bison was 
reported in our study for the first time. Thus, these wild ruminants should be considered as a potential reservoir of tetracycline-resistant T. pyogenes strains. Nevertheless, further investigation on determinants of tetracycline resistance and their association with mobile genetic elements in T. pyogenes are needed, especially to improve interpretive criteria important for susceptibility testing, and consequently to use the most appropriate antibiotic treatment of infections caused by this pathogen.

Supplementary Materials: The following are available online at https://www.mdpi.com/article/ 10.3390/antibiotics10040380/s1, Figure S1: Figure S1. Multiple nucleotide sequence alignment of different variants of the tet $\mathrm{W}$ gene., Table S1: Table S1. Origin and characteristics of Trueperella pyogenes isolates $(n=19)$ identified in this study, which have not been previously described.

Author Contributions: Conceptualization, E.K., I.S. and M.R.; funding acquisition, W.O., M.R.; methodology, E.K., I.S., D.C.-C., M.K.-S., A.M. and M.R.; resources, E.K., D.C.-C., M.K.-Ś, A.M. and M.R.; investigation, E.K., I.S.; formal analysis, E.K., I.S., M.S. and M.R.; writing-original draft preparation, E.K.; writing—review and editing, I.S., W.O., M.S., M.B. and M.R.; supervision, M.R. All authors have read and agreed to the published version of the manuscript.

Funding: This research was funded by the project "Complex project of European bison conservation by State Forests", which is financed by the Forest Found (Poland), contract no. OR.271.3.10.2017.

Institutional Review Board Statement: Not applicable.

Informed Consent Statement: Not applicable.

Data Availability Statement: The data presented in this study are available in the article or supplementary material.

Acknowledgments: The authors thank Barbara Chojnacka, Alicja Grzechnik and Małgorzata Murawska for excellent technical assistance.

Conflicts of Interest: The authors declare no conflict of interest.

\section{References}

1. Jost, B.H.; Billington, S.J. Arcanobacterium pyogenes: Molecular pathogenesis of an animal opportunist. Antonie Leeuwenhoek 2005, 88, 87-102. [CrossRef]

2. Rzewuska, M.; Kwiecień, E.; Chrobak-Chmiel, D.; Kizerwetter-Świda, M.; Stefańska, I.; Gieryńska, M. Pathogenicity and Virulence of Trueperella pyogenes: A Review. Int. J. Mol. Sci. 2019, 20, 2737. [CrossRef] [PubMed]

3. Yoshimura, H.; Kojima, A.; Ishimaru, M. Antimicrobial susceptibility of Arcanobacterium pyogenes isolated from cattle and pigs. J. Vet. Med. B Infect. Dis. Vet. Public Health 2000, 47, 139-143. [CrossRef] [PubMed]

4. Ribeiro, M.G.; Risset, R.M.; Bolaños, C.A.; Caffaro, K.A.; de Morais, A.C.; Lara, G.H.; Zamprogna, T.O.; Paes, A.C.; Listoni, F.J.; Franco, M.M. Trueperella pyogenes multispecies infections in domestic animals: A retrospective study of 144 cases (2002 to 2012). Vet. Q. 2015, 35, 82-87. [CrossRef] [PubMed]

5. Rzewuska, M.; Czopowicz, M.; Gawryś, M.; Markowska-Daniel, I.; Bielecki, W. Relationships between antimicrobial resistance, distribution of virulence factor genes and the origin of Trueperella pyogenes isolated from domestic animals and European bison (Bison bonasus). Microb. Pathog. 2016, 96, 35-41. [CrossRef]

6. Galán-Relaño, Á.; Gómez-Gascón, L.; Barrero-Domínguez, B.; Luque, I.; Jurado-Martos, F.; Vela, A.I.; Sanz-Tejero, C.; Tarradas, C. Antimicrobial susceptibility of Trueperella pyogenes isolated from food-producing ruminants. Vet. Microbiol. 2020, 242, 108593. [CrossRef]

7. Billington, S.J.; Post, K.W.; Jost, B.H. Isolation of Arcanobacterium (Actinomyces) pyogenes from cases of feline otitis externa and canine cystitis. J. Vet. Diagn. Investig. 2002, 14, 159-162. [CrossRef]

8. Trinh, H.T.; Billington, S.J.; Field, A.C.; Songer, J.G.; Jost, B.H. Susceptibility of Arcanobacterium pyogenes from different sources to tetracycline, macrolide and lincosamide antimicrobial agents. Vet. Microbiol. 2002, 85, 353-359. [CrossRef]

9. Wareth, G.; El-Diasty, M.; Melzer, F.; Murugaiyan, J.; Abdulmawjood, A.; Sprague, L.D.; Neubauer, H. Trueperella pyogenes and Brucella abortus coinfection in a dog and a cat on a dairy farm in Egypt with recurrent cases of mastitis and abortion. Vet. Med. Int. 2018, 2056436. [CrossRef]

10. Tell, L.A.; Brooks, J.W.; Lintner, V.; Matthews, T.; Kariyawasam, S. Antimicrobial susceptibility of Arcanobacterium pyogenes isolated from the lungs of white-tailed deer (Odocoileus virginianus) with pneumonia. J. Vet. Diagn. Investig. 2011, 23, 1009-1013. [CrossRef]

11. Rzewuska, M.; Stefańska, I.; Osińska, B.; Kizerwetter-Świda, M.; Chrobak, D.; Kaba, J.; Bielecki, W. Phenotypic characteristics and virulence genotypes of Trueperella (Arcanobacterium) pyogenes strains isolated from European bison (Bison bonasus). Vet. Microbiol. 2012, 160, 69-76. [CrossRef] 
12. Salleng, K.J.; Burton, B.J.; Apple, T.M.; Sanchez, S. Isolation of Trueperella pyogenes in a case of thoracic and abdominal abscess in a galago (Otolemur garnettii). J. Med. Primatol. 2016, 45, 198-201. [CrossRef]

13. Tarazi, Y.H.; Al-Ani, F.K. An Outbreak of dermatophilosis and caseous lymphadenitis mixed infection in camels (Camelus dromedaries) in Jordan. J. Infect. Dev. Ctries. 2016, 10, 506-511. [CrossRef]

14. Nagib, S.; Glaeser, S.P.; Eisenberg, T.; Sammra, O.; Lämmler, C.; Kämpfer, P.; Schauerte, N.; Geiger, C.; Kaim, U.; PrengerBerninghoff, E.; et al. Fatal infection in three Grey Slender Lorises (Loris lydekkerianus nordicus) caused by clonally related Trueperella pyogenes. BMC Vet. Res. 2017, 13, 273. [CrossRef]

15. Ülbegi-Mohyla, H.; Hijazin, M.; Alber, J.; Lämmler, C.; Hassan, A.A.; Abdulmawjood, A.; Prenger-Berninghoff, E.; Weiß, R.; Zschöck, M. Identification of Arcanobacterium pyogenes isolated by post mortem examinations of a bearded dragon and a gecko by phenotypic and genotypic properties. J. Vet. Sci. 2010, 11, 265-267. [CrossRef]

16. Galán-Relaño, Á.; Gómez-Gascón, L.; Luque, I.; Barrero-Domínguez, B.; Casamayor, A.; Cardoso-Toset, F.; Vela, A.I.; FernándezGarayzábal, J.F.; Tarradas, C. Antimicrobial susceptibility and genetic characterization of Trueperella pyogenes isolates from pigs reared under intensive and extensive farming practices. Vet. Microbiol. 2019, 232, 89-95. [CrossRef] [PubMed]

17. Plamondon, M.; Martinez, G.; Raynal, L.; Touchette, M.; Valiquette, L. A fatal case of Arcanobacterium pyogenes endocarditis in a man with no identified animal contact: Case report and review of the literature. Eur. J. Clin. Microbiol. Infect. Dis. 2007, 26, 663-666. [CrossRef] [PubMed]

18. Kavitha, K.; Latha, R.; Udayashankar, C.; Jayanthi, K.; Oudeacoumar, P. Three Cases of Arcanobacterium Pyogenes-Associated Soft Tissue Infection. J. Med. Microbiol. 2010, 59, 736-739. [CrossRef] [PubMed]

19. di Cerbo, A.; Pezzuto, F.; Guidetti, G.; Canello, S.; Corsi, L. Tetracyclines: Insights and updates of their use in human and animal pathology and their potential toxicity. Open Biochem. J. 2019, 13, 1-12. [CrossRef]

20. Lees, P.; Pelligand, L.; Giraud, E.; Toutain, P.L. A history of antimicrobial drugs in animals: Evolution and revolution. J. Vet. Pharmacol. Therap. 2020, 1-35. [CrossRef] [PubMed]

21. Michalova, E.; Novotna, P.; Schlegelova, J. Tetracyclines in veterinary medicine and bacterial resistance to them. Vet. Med. Czech 2004, 49, 79-100. [CrossRef]

22. Patyra, E.; Przeniosło-Siwczyńska, M.; Grelik, A.; Kwiatek, K. Występowanie tetracyklin w paszach-Przyczyny i skutki. Med. Weter. 2019, 75, 280-286. [CrossRef]

23. Mileva, R.; Karadaev, M.; Fasulkov, I.; Petkova, T.; Rusenova, N.; Vasilev, N.; Milanova, A. Oxytetracycline Pharmacokinetics after Intramuscular Administration in Cows with Clinical Metritis Associated with Trueperella pyogenes Infection. Antibiotics 2020, 9, 392. [CrossRef]

24. Roberts, M.C. Tetracyclines: Mode of Action and their Bacterial Mechanisms of Resistance. In Bacterial Resistance to AntibioticsFrom Molecules to Man; Bonev, B.B., Brown, N.M., Eds.; Wiley-Blackwell: Hoboken, NJ, USA, 2019; pp. 101-124.

25. Sheykhsaran, E.; Baghi, H.B.; Soroush, M.H.; Ghotaslou, R. An overview of tetracyclines and related resistance mechanisms. Rev. Med. Microbiol. 2019, 30, 69-75. [CrossRef]

26. Liu, M.C.; Wu, C.M.; Liu, Y.C.; Zhao, J.C.; Yang, Y.L.; Shen, J.Z. Identification, susceptibility, and detection of integron-gene cassettes of Arcanobacterium pyogenes in bovine endometritis. J. Dairy Sci. 2009, 92, 3659-3666. [CrossRef] [PubMed]

27. Santos, T.M.; Caixeta, L.S.; Machado, V.S.; Rauf, A.K.; Gilbert, R.O.; Bicalho, R.C. Antimicrobial resistance and presence of virulence factor genes in Arcanobacterium pyogenes isolated from the uterus of postpartum dairy cows. Vet. Microbiol. 2010, 145, 84-89. [CrossRef]

28. Zastempowska, E.; Lassa, H. Genotypic characterization and evaluation of an antibiotic resistance of Trueperella pyogenes (Arcanobacterium pyogenes) isolated from milk of dairy cows with clinical mastitis. Vet. Microbiol. 2012, 161, 153-159. [CrossRef] [PubMed]

29. de Boer, M.; Heuer, C.; Hussein, H.; McDougall, S. Minimum inhibitory concentrations of selected antimicrobials against Escherichia coli and Trueperella pyogenes of bovine uterine origin. J. Dairy Sci. 2015, 98, 4427-4438. [CrossRef]

30. Ozturk, D.; Turutoglu, H.; Pehlivanoglu, F.; Guler, L. Virulence Genes, Biofilm Production and Antibiotic Susceptibility in Trueperella pyogenes Isolated from Cattle. Isr. J. Vet. Med. 2016, 71, 36-42.

31. Alkasir, R.; Wang, J.; Gao, J.; Ali, T.; Zhang, L.; Szenci, O.; Bajcsy, A.C.; Han, B. Properties and antimicrobial susceptibility of Trueperella pyogenes isolated from bovine mastitis in China. Acta Vet. Hung. 2016, 64, 1-12. [CrossRef]

32. Momtaz, H.; Ghafari, A.; Sheikh-Samani, A.; Jhazayeri, A. Detecting Virulence Factors and Antibiotic Resistance Pattern of Trueperella Pyogenes Isolated from Bovine Mastitic Milk. Int. J. Med. Lab. 2016, 3, 134-141.

33. Zhang, D.; Zhao, J.; Wang, Q.; Liu, Y.; Tian, C.; Zhao, Y.; Yu, L.; Liu, M. Trueperella pyogenes isolated from dairy cows with endometritis in Inner Mongolia, China: Tetracycline susceptibility and tetracycline-resistance gene distribution. Microb. Pathog. 2017, 105, 51-56. [CrossRef] [PubMed]

34. Ashrafi Tamai, I.; Mohammadzadeh, A.; Zahraei Salehi, T.; Mahmoodi, P. Genomic characterisation, detection of genes encoding virulence factors and evaluation of antibiotic resistance of Trueperella pyogenes isolated from cattle with clinical metritis. Antonie Leeuwenhoek 2018, 111, 2441-2453. [CrossRef]

35. Rezanejad, M.; Karimi, S.; Momtaz, H. Phenotypic and molecular characterization of antimicrobial resistance in Trueperella pyogenes strains isolated from bovine mastitis and metritis. BMC Microbiol. 2019, 19, 305. [CrossRef]

36. Jost, B.H.; Field, A.C.; Trinh, H.T.; Songer, J.G.; Billington, S.J. Tylosin Resistance in Arcanobacterium pyogenes Is Encoded by an Erm X Determinant. Antimicrob. Agents Chemother. 2003, 47, 3519-3524. [CrossRef] [PubMed] 
37. Billington, S.J.; Jost, B.H. Multiple Genetic Elements Carry the Tetracycline Resistance Gene tet(W) in the Animal Pathogen Arcanobacterium pyogenes. Antimicrob. Agents Chemother. 2006, 50, 3580-3587. [CrossRef] [PubMed]

38. Kwiecień, E.; Stefańska, I.; Chrobak-Chmiel, D.; Sałamaszyńska-Guz, A.; Rzewuska, M. New Determinants of Aminoglycoside Resistance and Their Association with the Class 1 Integron Gene Cassettes in Trueperella pyogenes. Int. J. Mol. Sci. 2020, $20,4230$. [CrossRef] [PubMed]

39. CLSI. Methods for Antimicrobial Susceptibility Testing of Infrequently Isolated or Fastidious Bacteria Isolated from Animals, 1st ed.; CLSI Supplement VET06; Clinical and Laboratory Standards Institute: Wayne, PA, USA, 2017.

40. Palma, E.; Tilocca, B.; Roncada, P. Antimicrobial Resistance in Veterinary Medicine: An Overview. Int. J. Mol. Sci. 2020, $21,1914$. [CrossRef] [PubMed]

41. EMA. European Surveillance of Veterinary Antimicrobial Consumption; Sales of Veterinary Antimicrobial Agents in 31 European Countries in 2018; European Medicines Agency: Amsterdam, The Netherlands, 2020; p. 24309.

42. Krasucka, D.; Biernacki, B.; Szumiło, J.; Burmańczuk, A. Monitoring zużycia leków przeciwdrobnoustrojowych u bydła, trzody chlewnej I koni w Polsce w latach 2014-2016 na podstawie Programu Wieloletniego. Życie Weter. 2017, 92, 578-581.

43. European Food Safety Authority and European Centre for Disease Prevention and Control (EFSA and ECDC). The European Union Summary Report on Antimicrobial Resistance in zoonotic and indicator bacteria from humans, animals and food in 2017/2018. EFSA J. 2018, 18, 6007. [CrossRef]

44. Luo, L.; Zhang, C.; Zhang, Z.; Peng, J.; Han, Y.; Wang, P.; Kong, X.; Rizwan, H.M.; Zhang, D.; Su, P.; et al. Differences in Tetracycline Antibiotic Resistance Genes and Microbial Community Structure During Aerobic Composting and Anaerobic Digestion. Front. Microbiol. 2020, 11, 583995. [CrossRef] [PubMed]

45. Pohl, A.; Lübke-Becker, A.; Heuwieser, W. Minimum inhibitory concentrations of frequently used antibiotics against Escherichia coli and Trueperella pyogenes isolated from uteri of postpartum dairy cows. J. Dairy Sci. 2018, 101, 1355-1364. [CrossRef] [PubMed]

46. Fernández, E.P.; Vela, A.I.; Las Heras, A.; Domínguez, L.; Fernández-Garayzábal, J.F.; Moreno, M.A. Antimicrobial susceptibility of corynebacteria isolated from ewe's mastitis. Int. J. Antimicrob. Agents 2001, 18, 571-574. [CrossRef]

47. Krasińska, M.; Krasiński, Z.A. European Bison-The Nature Monograph; Mammal Research Institute, Polish Academy of Sciences: Białowieża, Poland, 2007; pp. 141-191.

48. Klich, D.; Łopucki, R.; Stachniuk, A.; Sporek, M.; Fornal, E.; Wojciechowska, M.; Olech, W. Pesticides and conservation of large ungulates: Health risk to European bison from plant protection products as a result of crop depredation. PLoS ONE 2020, 15, e0228243. [CrossRef] [PubMed]

49. Chirino-Trejo, M.; Woodbury, M.R.; Huang, F. Antibiotic sensitivity and biochemical characterization of Fusobacterium spp. and Arcanobacterium pyogenes isolated from farmed white-tailed deer (Odocoileus virginianus) with necrobacillosis. J. Zoo Wildl. Med. 2003, 34, 262-268. [CrossRef]

50. Connell, S.R.; Tracz, D.M.; Nierhaus, K.H.; Taylor, D.E. Ribosomal protection proteins and their mechanism of tetracycline resistance. Antimicrob. Agents Chemother. 2003, 47, 3675-3681. [CrossRef]

51. Barbosa, T.M.; Scott, K.P.; Flint, H.J. Evidence for recent intergeneric transfer of a new tetracycline resistance gene, tet $(W)$, isolated from Butyrivibrio fibrisolvens, and the occurrence of tet $(O)$ in ruminal bacteria. Environ. Microbiol. 1999, 1, 53-64. [CrossRef] [PubMed]

52. Melville, C.M.; Brunel, R.; Flint, H.J.; Scott, K.P. The Butyrivibrio fibrisolvens tet(W) Gene Is Carried on the Novel Conjugative Transposon TnB1230, Which Contains Duplicated Nitroreductase Coding Sequences. J. Bacteriol. 2004, 186, 3656-3659. [CrossRef]

53. Stanton, T.B.; McDowall, J.S.; Rasmussen, M.A. Diverse Tetracycline Resistance Genotypes of Megasphaera elsdenii Strains Selectively Cultured from Swine Feces. Appl. Environ. Microbiol. 2004, 70, 3754-3757. [CrossRef]

54. Kazimierczak, K.A.; Flint, H.J.; Scott, K.P. Comparative Analysis of Sequences Flanking tet(W) Resistance Genes in Multiple Species of Gut Bacteria. Antimicrob. Agents Chemother. 2006, 50, 2632-2639. [CrossRef]

55. Ammor, M.S.; Flórez, A.B.; Alvarez-Martín, P.; Margolles, A.; Mayo, B. Analysis of Tetracycline Resistance tet(W) Genes and Their Flanking Sequences in Intestinal Bifidobacterium Species. J. Antimicrob. Chemother. 2008, 62, 688-693. [CrossRef]

56. Billington, S.J.; Songer, J.G.; Jost, B.H. Widespread Distribution of a Tet W Determinant among Tetracycline-Resistant Isolates of the Animal Pathogen Arcanobacterium pyogenes. Antimicrob. Agents Chemother. 2002, 46, 1281-1287. [CrossRef] [PubMed]

57. Villedieu, A.; Diaz-Torres, M.L.; Hunt, N.; McNab, R.; Spratt, D.A.; Wilson, M.; Mullany, P. Prevalence of Tetracycline Resistance Genes in Oral Bacteria. Antimicrob. Agents Chemother. 2003, 47, 878-882. [CrossRef]

58. Tauch, A.; Götker, S.; Pühler, P.; Kalinowski, J.; Thierbach, G. The 27.8-kb R-plasmid pTET3 from Corynebacterium glutamicum encodes the aminoglycoside adenyltransferase gene cassette aadA9 and the regulated tetracycline efflux system Tet 33 flanked by active copies of the widespread insertion sequence IS6100. Plasmid 2002, 48, 117-129. [CrossRef]

59. Dong, W.L.; Xu, Q.J.; Atiah, L.A.; Odah, K.A.; Gao, Y.H.; Kong, L.C.; Ma, H.X. Genomic island type IV secretion system and transposons in genomic islands involved in antimicrobial resistance in Trueperella pyogenes. Vet. Microbiol. 2020, $242,108602$. [CrossRef] [PubMed]

60. Doidge, C.; Ruston, A.; Lovatt, F.; Hudson, C.; King, L.; Kaler, J. Farmers' Perceptions of Preventing Antibiotic Resistance on Sheep and Beef Farms: Risk, Responsibility, and Action. Front. Vet. Sci. 2020, 7, 524. [CrossRef]

61. Santamaría, J.; López, L.; Soto, C.Y. Detection and Diversity Evaluation of Tetracycline Resistance Genes in Grassland-Based Production Systems in Colombia, South America. Front. Microbiol. 2011, 2, 252. [CrossRef] 
62. Girlich, D.; Bonnin, R.A.; Naas, T. Occurrence and Diversity of CTX-M-Producing Escherichia coli From the Seine River. Front. Microbiol. 2020, 11, 603578. [CrossRef]

63. Chee-Sanford, J.C.; Aminov, R.I.; Garrigues-Jeanjean, N.; Mackie, R.I. Occurrence and Diversity of Tetracycline Resistance Genes in Lagoons and Groundwater Underlying Two Swine Production Facilities. Appl. Environ. Microbiol. 2001, 67, 1494-1502. [CrossRef] [PubMed]

64. Kyselková, M.; Jirout, J.; Vrchotová, N.; Schmitt, H.; Elhottová, D. Spread of Tetracycline Resistance Genes at a Conventional Dairy Farm. Front. Microbiol. 2015, 6, 536. [CrossRef] [PubMed]

65. Oliveira de Araujo, G.; Huff, R.; Favarini, M.O.; Mann, M.B.; Peters, F.B.; Frazzon, J.; Guedes Frazzon, A.P. Multidrug Resistance in Enterococci Isolated from Wild Pampas Foxes (Lycalopex gymnocercus) and Geoffroy's Cats (Leopardus geoffroyi) in the Brazilian Pampa Biome. Front. Vet. Sci. 2020, 7, 606377. [CrossRef] [PubMed]

66. Gevers, D.; Danielsen, M.; Huys, G.; Swings, J. Molecular characterization of tet(M) genes in Lactobacillus isolates from different types of fermented dry sausage. Appl. Environ. Microbiol. 2003, 69, 1270-1275. [CrossRef] [PubMed]

67. Pang, Y.; Bosch, T.; Roberts, M.C. Single polymerase chain reaction for the detection of tetracycline-resistant determinants Tet K and Tet L. Mol. Cell. Probes 1994, 8, 417-422. [CrossRef] [PubMed]

68. Nawaz, M.; Wang, J.; Zhou, A.; Ma, C.; Wu, X.; Moore, J.E.; Millar, B.C.; Xu, J. Characterization and transfer of antibiotic resistance in lactic acid bacteria from fermented food products. Curr. Microbiol. 2011, 62, 1081-1090. [CrossRef]

69. Gibreel, A.; Tracz, D.M.; Nonaka, L.; Ngo, T.M.; Connell, S.R.; Taylor, D.E. Incidence of Antibiotic Resistance in Campylobacter jejuni Isolated in Alberta, Canada, from 1999 to 2002, with Special Reference to tet(O)-Mediated Tetracycline Resistance. Antimicrob. Agents Chemother. 2004, 48, 3442-3450. [CrossRef]

70. Trzciński, K.; Cooper, B.S.; Hryniewicz, W.; Dowson, C.G. Expression of resistance to tetracyclines in strains of methicillin-resistant Staphylococcus aureus. J. Antimicrob. Chemother. 2000, 45, 763-770. [CrossRef]

71. CLSI. Performance Standards for Antimicrobial Disk and Dilution Susceptibility Tests for Bacteria Isolated from Animals, 4th ed.; Approved Standard. CLSI Document VET01-A4; Clinical and Laboratory Standards Institute: Wayne, PA, USA, 2013.

72. CLSI. Performance Standards for Antimicrobial Disk and Dilution Susceptibility Tests for Bacteria Isolated from Animals, 4th ed.; CLSI Supplement VET08; Clinical and Laboratory Standards Institute: Wayne, PA, USA, 2018.

73. Altschul, S.F.; Madden, T.L.; Schäffer, A.A.; Zhang, J.; Zhang, Z.; Miller, W.; Lipman, D.J. Gapped BLAST and PSI-BLAST: A new generation of protein database search programs. Nucleic Acids Res. 1997, 25, 3389-3402. [CrossRef]

74. Saitou, N.; Nei, M. The neighbor-joining method: A new method for reconstructing phylogenetic trees. Mol. Biol. Evol. 1987, 4, 406-425. [CrossRef]

75. Tamura, K.; Nei, M.; Kumar, S. Prospects for inferring very large phylogenies by using the neighbor-joining method. Proc. Natl. Acad. Sci. USA 2004, 101, 11030-11035. [CrossRef]

76. Kumar, S.; Stecher, G.; Li, M.; Knyaz, C.; Tamura, K. MEGA X: Molecular Evolutionary Genetics Analysis across computing platforms. Mol. Biol. Evol. 2018, 35, 1547-1549. [CrossRef]

77. Felsenstein, J. Confidence limits on phylogenies: An approach using the bootstrap. Evolution 1985, 39, 783-791. [CrossRef] [PubMed] 